\title{
TANGGAPAN PADA SANKSI HUKUM PIDANA ISLAM HAD ZINA TERHADAP SIKAP TAUBATAN NASHUHA
}

\author{
Siti Muhayati
}

\begin{abstract}
Abstrak
Tujuan penelitian ini untuk mengetahui tanggapan (masa lalu "kognitif", ; masa sekarang "pengalaman"; masa yang akan datang "harapan"/imajinasi) pada sanksi hukum pidana Islam had zina terhadap sikap taubatan nashuha. Hasil penelitian menunjukan bahwa kognitif diisi dengan ilmu had zina maka mereka selalu bersikap taubatan nashuha, $\mathrm{r}_{10}=\mathrm{y}_{1 \mathrm{t}}=0$; pengalaman diri dan orang lain pada had zina membuat mereka tetap taubatan nashuha, $\mathrm{r}_{20}=\mathrm{y}_{20}=0$; harapan had zina sebagai antisipasi membuat mereka tetap bersikap taubatan nashuhai, $\mathrm{r}_{30}=\mathrm{y}_{3 \mathrm{t}}=0$. Ilmu, pengalaman dan harapan zina sebagai antisipasi berpengaruh terhadap sikap taubatan nashuha $\mathrm{r}_{\mathrm{o}}=\mathrm{y}_{\mathrm{t}}=0$ atau tidak ada beda antara tanggapan pada sanksi hukum pidana Islam dan sikap taubatan nashuha.
\end{abstract}

Kata kunci: Tanggapan, Had Zina, Sikap, Taubatan Nashuha

* Siti Muhayati adalah Dosen Program Studi Bimbingan dan Konseling Fakultas Ilmu Pendidikan IKIP PGRI Madiun. 


\section{Pendahuluan}

Mayoritas siswa Indonesia beragama Islam. Potensi iman mereka terbentuk sejak dalam rohim (Q.S.Al-A'rof:172), baik oleh Allah (internal) maupun orang tua mereka masing-masing (eksternal). Anak lahir diasuh dengan pola asuh dialogis. Mulai anak usia 0-7 tahun, tahap berikutnya, orang tua berkolaborasi dengan para pendidik di lingkungan sekolah maupun dengan ulama di lingkungan masysrarakat.

Di lingkungan sekolah mereka mendapat pendidikan Agama Islam dimana, kurikulumnya disusun oleh ulama Islam yang mendapat amanah di Kementerian Agama, dalam hal ini Depertemen Agama bidang pendidikan Islam. Kurikulum tersebut dibuat untuk anak usia Taman Kanak-Kanak sampai Sekolah Menengah Atas atau Sekolah Menengah Kejuruan. Materi Islam yang dijabarkan dalam Kurikulum adalah tentang Iman, hukum Islam dan Akhlaq. Had Zina termasuk dalam lingkup hukum Islam.

Di lingkungan masyarakat, siswa tidak banyak mendapat materi pendidikan Islam terutama yang terkait dengan hukum dan had zina, bahkan sering mendapat informasi lisan dan visual yang seakan dibolehkan mendekati dan melakukan zina.

Tiap hari siswa usia sekolah lebih banyak waktunya di lingkungan keluarga dan lingkungan sekolah, sedikit waktu di lingkungan masyarakat. Maka idealnya siswa usia sekolah tidak mendekati zina dan melakukan zina. Jika mereka telah melakukan zina maka mereka bersegera taubatan nashuha.

Tapi melalui media sering didengar siswa usia sekolah mendekati, dan melakukan zina merupakan hal biasa yang mereka anggap bagian dari masa remaja. Bahkan tidak didengar mereka bertaubat.

Dari uraian diatas mendorong penulis mengadakan penelitian dengan judul Tanggapan pada Sanksi Hukum Pidana Islam Had Zina Terhadap Sikap Taubatan Nashuha.

Perumusan Masalahnya adalah: sejauh mana tanggapan masa lalu siswa pada had zina terhadap kognisi untuk taubatan nashuha ?; Sejauh mana tanggapan masa kini siswa pada had zina terhadap afeksi untuk taubatan nashuha ?; Sejauh mana tanggapan masa datang siswa pada had zina terhadap psikomotorik untuk taubatan nashuha ?; Sejauh mana tanggapan siswa pada had zina terhadap sikap taubatan nashuha?

\section{Definisi Istilahnya adalah: Tanggapan.}

Dalam penelitian ini, tanggapan adalah: 1. Tanggapan masa lampau atau tanggapan ingatan; 2. Tanggapan masa kini atau tanggapan representative, mengimajinasikan 3. Tanggapan masa datang atau tanggapan mengantisipasi (Wasty Soemanto). Ketiga tanggapan tersebut baik dari hasil pengamatan visual, 
auditif, ingatan, fantasi, kata. Indikatornya Tanggapan masa lampau (pengalaman), Tanggapan masa kini (rasa), Tanggapan masa datang (antisipasi).

Had Zina. Had zina adalah sanksi yang telah ditetapkan oleh Allah untuk penjeraan pelaku zina. Dalam penelitian ini adalah zina ghoiru muhshon ya'ni zina yang dilakukan orang yang belum pernah menikah. Indikatornya Pelaku zina laki-laki, pelaku zina perempuan, perbuatan dan mendekati zina, sanksi hukum.

Sikap. Sikap adalah pernyataan evaluatif terhadap objek, orang atau peristiwa. Hal ini mencerminkan perasaan seseorang terhadap sesuatu. Sikap mempunyai tiga komponen utama: kesadaran, perasaan, dan perilaku. Indikatornya yaitu kesadaran, perasaan dan perilaku.

Taubatan Nashuha. Taubatan nashuha adalah suatu perasaan, keyakinan dan perbuatan individu yang berpindah dari perbuatan buruk ke perbuatan baik yang terus menerus dan istiqomah.

Pada hakekatnya taubat jika dilihat dari aspek kejiwaan adalah suatu kombinasi dari fungsi-fungsi kejiwaan yang mampu merevitalisasi kondisi psikologis manusia. Fungsi-fungsi kejiwaan tersebut antara lain: Kesadaran; Pengakuan dosa (al I'tiraf); Penyesalan (al Nadam); Komitmen; Perbuatan baik yang terus menerus. Indikatornya adalah Kesadaran, Pengakuan dosa (al I'tiraf), Penyesalan (al Nadam), Komitmen, Perbuatan baik yang terus.

\section{Tujuan Penelitian}

Tujuan penelitian ini untuk mengetahui: Hubungan tanggapan masa lalu siswa pada had zina terhadap kognisi untuk taubatan nashuha; Hubungan tanggapan masa kini siswa pada had zina terhadap afeksi untuk taubatan nashuha; Hubungan tanggapan masa datang siswa pada had zina terhadap psikomotorik untuk taubatan nashuha; Hubungan tanggapan siswa pada had zina terhadap sikap taubatan nashuha.

Manfaat Penelitian.

Hasil penelitian ini diharapkan dapat memberikan manfaat sebagai berikut: Manfaat Teoretis: secara teoretis penelitian ini diharapkan mampu memberikan sumbangan bagi pengembangan ilmu pengetahuan, khususnya bagi ilmu psikologi dalam kaitannya dengan sikap untuk taubatan nashuha; serta bagi ilmu hokum tentang sanksi hukum pidana Islam had zina. Manfaat Praktis: hasil penelitian ini diharapkan dapat bermanfaat bagi: siswa mampu memaknai sanksi hukum pidana had zina jika dijatuhkan maka mereka mampu melakukan taubatan nashuha; Bagi Sekolah: rajin memantau siswanya agar tidak mendekati dan melakukan zina; Bagi orang Tua: Orangtua mempraktekkan pola asuh dialogis atau Illahiyah agar anak tidak mendekati dan melakukan zina. 
Pembahasan

1. Konsepsi

a. Tanggapan

Tanggapan adalah gambaran ingatan dari pengamatan dalam mana obyek yang telah diamati tidak lagi berada dalam ruang dan waktu pengamatan (Abu Ahmadi, 2003:64). Tanggapan yaitu suatu bayangan yang ada dalam ingatan setelah seseorang melakukan pengamatan dan obyek yang diamati tidak lagi dalam ruang dan waktu pengamatan (Abu Ahmadi, 2009:68).

Tanggapan ialah pengalaman kembali atau penghayatan kembali bekas-bekas yang diterima dahulu dari pengamatan, yang sekarang digambarkan kembali dalam kesadaran (Sumadi Suryabrata: 1998). Tanggapan didefisinikan sebagai gambaran ingatan dalam jiwa manusia yang terjadi setelah obyek yang diamati sudah tidak berada lagi dalam ruang dan waktu pengamatan (Ita Rezki Amalia, 2012:24).

Tanggapan disebut laten (tersembunyi, belum terungkap), apabila tanggapan tersebut ada dibawah sadar, atau tidak kita sadari, dan suatu saat bisa disadarkan kembali. Sedang tanggapan disebut actual, apabila tanggapan disadari (Abu Ahmadi, 2009:68), tanggapan dapat dihidupkan kembali baik tanggapan dimasa lalu, sekarang maupun yang akan datang (Sumadi Suryabrata, 1998).

Tanggapan merupakan kesan dari pengamatan. Menurut teori tanggapan, belajar adalah memasukan tanggapan sebanyak-banyaknya, berulang-ulang, dan sejelas-jelasnya. Banyak tanggapan berarti dikatakan pandai, sedikit tanggapan berarti dikatakan kurang pandai, maka orang pandai berarti orang yang banyak mempunyai tanggapan yang tersimpan dalam otaknya (Syaiful Bahri Djamarah, 2011:18), dalam istilah pendidikan dikatakan bahwa pengetahuan yang baru mudah diterima jika sudah ada pengetahuan yang lama yang berhubungan atau bersamaan dengan itu. Seseorang mudah memahami pengetahuan baru jika seseorang tersebut dalam otaknya sudah banyak pengetahuan yang berhubungan atau bersamaan dengan itu. Tanggapan-tanggapan yang bertalian satu sama lainnya mempunyai kecenderungan untuk saling memproduksikan artinya apabila yang satu disadari maka yang lain ikut disadari pula. Orang yang banyak tanggapan maka mudah memahami segala hal jika suatu hal yang baru itu sudah ada ada dalam otaknya (Sumadi Suryabrata, 1998).

Tanggapan ada tiga macam yaitu: Tanggapan masa lampau atau tanggapan ingatan; Tanggapan masa datang atau tanggapan mengantisipasi; Tanggapan masa kini atau tanggapan representatif/ 
mengimajinasikan (Wasty Soemanto). Tokoh lain membedakan tanggapan sebagai berikut: 1) menurut alat indera yang berperanan dalam waktu mengamati: ada tanggapan Visual (penglihatan), Auditif (pendengaran), penciuman, dan sebagainya; 2) menurut terjadinya: ada tanggapan ingatan, ada tanggapan fantasi. 3) menurut terikatnya: tanggapan benda dan ada tanggapan kata (Sumadi Suryabrata, 1998).

Tipe tanggapan adalah Bayangan Identik; Proses Pengiring; Reproduksi; Asosiasi; Apersepsi (Suryabrata Sumadi, 1998). Faktor yang mempengaruhi tanggapan adalah Faktor dukungan; Faktor Rintangan (Sumadi Suryabrata, 1998).

Pembentukan tanggapan adalah suatu proses mental yang fundamental. Tanggapan bersifat pribadi; tanggapan reproduksi dan imaginer seseorang tidak dapat diketahui oleh orang lain kecuali pada saat mereka berfungsi yang diperlihatkan dalam tingkah laku. Walaupun latar belakang pengalaman memegang suatu peranan penting dalam proses imaginatif, tanggapan cenderung tidak stabil dan tidak dapat dipercaya karena mereka dapat menjadi bertambah kabur dari pembentukannya yang asli sesuai dengan bertambahnya waktu yang berlangsung.

Konsep Tanggapan dalam penelitian ini adalah Tanggapan masa lampau atau tanggapan ingatan; Tanggapan masa datang atau tanggapan mengantisipasi; Tanggapan masa kini atau tanggapan representative, mengimajinasikan (Wasty Soemanto). Ketiga tanggapan tersebut baik dari hasil pengamatan visual, auditif, ingatan, fantasi, kata.

b. Hukum Pidana Islam Had Zina

Hukum Pidana Islam dalam konsepsi ini adalah Hukum Pidana Islam. Hukum Pidana Islam dalam literatur Islam disebut al-ahkamuljinayah, yaitu peraturan yang mengatur pelanggaran-pelanggaran yang dilakukan oleh orang mukallaf dan hukuman-hukuman baginya. Hukum pidana Islam mengatur tiga hal yaitu:

1) Hudud

Yang dimaksud dengan hukuman hudûd adalah hukuman tertentu yang telah ditetapkan oleh Syari', baik dalam Alqur'an atau Sunnah Nabi Muhammad s.a.w., yang berupa perbuatan maupun perkataan. Dalam Alqur'an, kalimat had atau hudûd tidak ada yang berarti hukuman, namun berarti perintah atau larangan, atau berkaitan dengan hukum Allah, yang jika hudûd tersebut dilanggar maka ia mendapat adzab dari Allah, maka 
arti hudûd sebagai hukuman merupakan istilah yang diberikan oleh para ulama fiqh.

'Asymâwî menegaskan, bahwa yang perlu diperhatikan dalam penerapan hukuman hudûd secara umum adalah: pertama, sudah terbentuk masyarakat yang adil sebagaimana metode Allah dalam menurunkan perintah dalam Alqur'an; kedua, penerapan hukuman hudûd ini dimaksudkan untuk menegakkan keadilan dan keamanan dalam bidang ekonomi, sosial dan politik, bukan sekedar menerapkan hukuman; ketiga, hukuman hudûd bukan permainan yang bisa diterapkan tanpa syarat yang ketat, ia harus dilaksanakan dengan berlandaskan takwa, keimanan dan keadilan( Al'Asymâwi, 1996:264-265).

Pelanggaran yang dapat dikenai hukuman had dalah:

1). Pencurian, 2) Perampokan, 3) Qodaf, menuduh berbuat nista. 4) Zina, 5) Murtad, 6) Minum minuman keras. Jadi zina termasuk perbuatan pidana yang telah ditentukan hukumannya.

Zina adalah persetubuhan yang dilakukan oleh seorang laki-laki dan seorang perempuan yang tidak menikah lebih dulu. Hukuman akibat perbuatan zina terbagi menjadi tiga bagian: Pertama, firman Allah dalam Al-qur'an surat Al-Nisâ' (4) ayat 15,Artinya:

Dan (terhadap) para wanita yang mengerjakan perbuatan keji, hendaklah ada empat orang saksi diantara kamu (yang menyaksikannya). Kemudian apabila mereka telah memberi persaksian, maka kurunglah mereka (wanita-wanita itu) dalam rumah sampai mereka menemui ajalnya, atau sampai Allah memberi jalan lain kepadanya.

Ayat diatas menerangkan bahwa hukuman bagi seorang yang berbuat zina ditahan di dalam rumah hingga meninggal atau Allah akan memberikan jalan yang lain. Ayat yang kedua adalah firman Allah dalam Al-qur'an surat al-Nisâ' (4) ayat 16,Artinya:

Dan terhadap dua orang yang melakukan perbuatan keji di antara kamu, maka berilah hukuman kepada keduanya, kemudian jika keduanya bertaubat dan memperbaiki diri, maka biarkanlah mereka. Sesungguhnya Allah Maha Penerima taubat lagi Maha Penyayang.

Ayat tersebut diatas menerangkan bahwa hukuman bagi seseorang yang berbuat zina adalah $a l-\hat{\imath} d z a^{\prime}$ (hukuman) tanpa dibatasi macamnya, yang ketentuannya diserahkan kepada wali dan disesuaikan dengan kondisinya (Al-'Asymâwi, 1996: 120). Ayat 
yang ketiga adalah firman Allah dalam Al-qur'an surat al-Nûr (24) ayat 2:Artinya

Perempuan yang berzina dan laki-laki yang berzina, maka deralah tiap-tiap seorang dari keduanya seratus dali dera, dan janganlah belas kasihan kepada keduanya mencegah kamu untuk (menjalankan) agama Allah, jika kamu beriman kepada Allah, dan hari akhirat, dan hendaklah (pelaksanaan) hukuman mereka disaksikan oleh sekumpulan orang-orang yang beriman.

Ayat tersebut diatas menerangkan bahwa hukuman bagi seseorang yang berbuat zina adalah hukuman cambuk 100 kali.

Ketiga ayat tersebut menerangkan hukuman yang berbedabeda bagi pelaku zina. Namun, terdapat Hadits Nabi yang menganjurkan hukuman rajam bagi seseorang yang berbuat zina. Dalam hal ini ada yang berpendapat bahwa keputusan Nabi Muhammad tersebut diambil dari firman Allah yang telah dinaskh namun hukumnya masih berlaku, yaitu firman Allah yang berbunyi;Artinya:

Jika seorang laki-laki dan perempuan berzina maka rajamlah keduanya sebagai hukuman dari Allah, dan sesungguhnya Allah Maha Mulia lagi Maha Bijaksana

Dengan demikian, meskipun ayat tersebut telah dihapus namun hukumnya tetap, ini menandakan bahwa hukuman rajam lebih baik dipertahankan demi kemaslahatan daripada harus dihapus sebagaimana ayat tersebut dinaskh. (Al-'Asymâwi, 1996: 120).

Hal tersebut dikuatkan dengan Hadits Nabi Muhammad s.a.w. yang berbunyi; Artinya:

Nabi s.a.w. bersabda: Para janda didera 100 kali kemudian dirajam dan jika ia seorang gadis didera 100 kali dan diasingkan selama setahun.:( Muslim, Shahih Muslim, hadits no. 3200).

Sedangkan sebagian ulama yang lainnya berpendapat bahwa hukuman bagi seseorang yang berbuat zina adalah hukuman cambuk baik bagi yang muhshin atau ghoiru muhshin. Pendapat ini didasarkan pada dzâhir dari teks ayat Alqur'an, dengan kemungkinan bahwa Hadist yang menerangkan tentang adanya hukum rajam diturunkan sebelum ayat tentang jild (dera) turun. (Muslim, Shahih Muslim, Hadits No. 3200).

Untuk mendapat penentuan hukuman yang sebenarnya hendaknya kita merujuk pada sebab turunnya ayat. Bahwa perintah 
Nabi Muhammad untuk merajam pelaku zina dikarenakan perbuatan itu dilakukan antara lelaki Yahudi dan wanita Yahudi, yang kemudian mereka mengadu kepada Rasulullah agar tidak dihukum seperti yang tercantum dalam Taurat, yaitu rajam, yang berbunyi: "Jika terdapat lelaki yang bersetubuh/berbaring bersama wanita yang beristri maka keduanya berhak dibunuh: lelaki yang menggauli dan wanita itu sendiri sehingga akan hilang/lenyap keburukan dari Bani Israil" karena pengaduan tersebut maka turunlah hukum dalam Al-qur'an surat al-Mâidat (05) ayat 43-47.

Artinya:

Dan bagaimanakah mereka mengangkatmu menjadi hakim mereka, padahal mereka mempunyai Taurat yang didalamnya (ada) hukum Allah, kemudian mereka berpaling sesudah itu (dari putusanmu)? Dan mereka sungguh-sungguh bukan orang yang beriman(43). Sesungguhnya Kami telah menurunkan Kitab Taurat di dalamnya (ada) petunjuk dan cahaya (yang menerangi), yang dengan Kitab itu diputuskan perkara orang-orang Yahudi oleh nabi-nabi yang menyerah diri kepada Allah, oleh orang-orang alim mereka dan pendeta-pendeta mereka, disebabkan mereka diperintahkan memelihara kitab-kitab Allah dan mereka menjadi saksi terhadapnya. Karena itu janganlah kamu takut kepada manusia, (tetapi) takutlah kepada-Ku. Dan janganlah kamu menukar ayat-ayat-Ku dengan harga yang sedikit. Barangsiapa yang tidak memutuskan menurut apa yang diturunkan Allah, maka mereka itu adalah orang-orang yang kafir (44). Dan Kami telah tetapkan terhadap mereka di dalamnya (At Taurat) bahwasanya jiwa (dibalas) dengan jiwa, mata dengan mata, hidung dengan hidung, telinga dengan telinga, gigi dengan gigi, dan luka luka (pun) ada kisasnya. Barangsiapa yang melepaskan (hak kisas) nya, maka melepaskan hak itu (menjadi) penebus dosa baginya. Barangsiapa tidak memutuskan perkara menurut apa yang diturunkan Allah, maka mereka itu adalah orang-orang yang zalim (45). Dan Kami iringkan jejak mereka (nabi nabi Bani Israil) dengan Isa putera Maryam, membenarkan Kitab yang sebelumnya, yaitu: Taurat. Dan Kami telah memberikan kepadanya Kitab Injil sedang didalamnya (ada) petunjuk dan dan cahaya (yang menerangi), dan membenarkan kitab yang sebelumnya, yaitu Kitab Taurat. Dan menjadi petunjuk serta pengajaran untuk orang-orang yang bertakwa (46). Dan hendaklah orang-orang pengikut Injil, memutuskan perkara menurut apa yang diturunkan Allah didalamnya. Barangsiapa tidak memutuskan perkara menurut apa yang diturunkan Allah, maka mereka itu adalah orang-orang yang fasik (47). 
Kemudian Nabi menyuruh untuk menghukum kedua pezina tersebut dengan hukuman rajam sesuai yang tercantum dalam kitab Taurat.

Telah diketahui bersama bahwa kedudukan Al-qur'an lebih tinggi dari Hadits Rasulullah karena ia merupakan penjelas terhadap ayat-ayat Al-qur'an. Al-'Asymâwi kemudian menegaskan bahwa ayat Al-qur'an hanya bisa dinaskh dengan ayat Al-qur'an dan Hadits tidak bisa menaskhAl-qur'an (Al-'Asymâwi, 1996: 121).

Maka hukuman bagi pezina adalah cambuk bukan rajam karena ayat Al-qur'an turun setelah perintah Nabi untuk merajam pezina. Namun setelah Nabi Muhammad meninggal, para sahabat berselisih tentang hal tersebut dan mengatakan: "Kami menghukum cambuk berdasarkan Al-qur'an dan merajam berdasarkan Hadits Nabi”. Menurut 'Asymâwi pendapat ini perlu dipertanyakan karena tidak mungkin kejahatan yang sama mempunyai hukuman yang berbeda tanpa ada nash yang jelas. Karena Sunnah Nabi hanya menerangkan dan menafsirkan bukan merubah atau menghapus ayat Al-qur'an (Al-'Asymâwi, 1996: 121).

Selain itu, dalam pelaksanaannya harus memenuhi syaratsyarat, yaitu: Harus disaksikan dengan empat orang adil dengan mata kepala mereka sendiri dari awal hingga akhir ketika perbuatan tersebut dilakukan, bahkan saksi harus yakin kalau kedua pezina tersebut tidak tertutupi oleh selembar benang pun. Kurangnya saksi atau keraguan yang menimpa salah seorang dari mereka, dan terbuktinya kebohongan salah seorang dari mereka, justru akan menimpakan sanksi qadzaf atas keseluruhan mereka.

2) Qishosh-Diyat

Qishosh/Diyat adalah jenis tindak pidana yang hukumannya berupa perlakuan yang sama atau setimpal. Perbuatan yang termasuk qishosh diyat adalah: Pembunuhan sengaja, tidak sengaja, semi sengaja; Perlukaan sengaja, tidak sengaja.

3) $T a$ 'zîr

Ta'zir dalam Al-qur'an berarti ta'dzîm (pengagungan dengan kejahatan yang dilakukan), seperti yang tertera dalam Al-qur'an suratal-Fath (49) ayat 09; Artinya:

Supaya kamu sekalian beriman kepada Allah dan Rasul-Nya, menguatkan (agama)Nya, membesarkan-Nya. Dan bertasbih kepada-Nya di waktu pagi dan petang. Namun dalam istilah fiqh ta'zîr berubah maknanya menjadi ta'dîb 
(pendidikan akhlak) yaitu jika terdapat seseorang yang berbuat tindakan membahayakan maka ia dididik dan diarahkan kepada kebaikan agar melaksanakan perintah Allah dan menolong masyarakat agar terhindar dari kejahatan sosial (Asymawi, 1996:81).

Ta'zîr adalah hukuman yang tidak terdapat dalam nash Alqur'an atau Hadits yang menerangkan tentang ketetapannya sehingga seorang hakim diberi kebebasan dalam memutuskan hukuman terhadap suatu perkara. Al-qur'an dan Hadits Nabi belum menerangkan tentang setiap perbuatan yang terjadi saat ini dan yang akan datang, keduanya hanya menerangkan tentang hukum suatu perkara yang terjadi pada saat itu saja. Sehingga ketika terjadi perubahan kondisi perlu ijtihad baru yang mungkin berakibat pada keputusan bahwa suatu perbuatan dianggap salah yang sebelumnya tidak dianggap salah, atau menghukumi seseorang dengan hukuman yang lebih berat atau dengan hukuman yang lebih ringan (Asymawi, 1996:129).

Hukuman $\underline{h}$ ad dalam Islam hanya membahas enam macam kejahatan, sedangkan selain kejahatan tersebut masih terdapat kejahatan yang lebih besar dan kejam seperti, korupsi, suap, penghamburan uang negara, pembajakan, homo seksual, narkoba, pacaran, free sex dan lain sebagainya yang membutuhkan hukuman yang jelas, karena jika tidak maka akan membahayakan keamanan masyarakat. Dalam kejahatan tersebut yang hukumnya

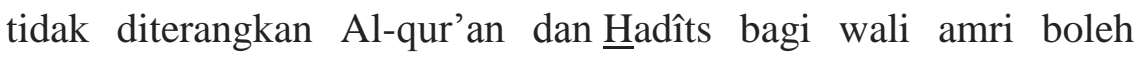
menerapkan hukuman melalui ta'zîr(Asymawi, 1996:81).

Ta'zîr juga diberlakukan bagi tindakan pidana yang tertera dalam Al-qur'an dan Hadits namun tidak memenuhi persyaratan tertentu, sedangkan tidak mungkin kejahatan tersebut dibiarkan tanpa hukuman yang bisa menyebabkan kejahatan semakin meluas, maka ta'zîr sangat diperlukan dan hakim boleh menentukan hukuman sesuai dengan maslahat dan ijtihad beliau yaitu melalui ta'zîr(Asymawi, 1996:129).

Hukuman $t a$ 'zîr bukan merupakan hukuman syar'i namun ia hanya merupakan hasil ijtihad ulama dan merupakan hasil pemikiran manusia. Pembedaan ini penting, karena pencampuran antara wahyu Allah dan hasil pemikiran manusia akan mensakralkan hasil ijtihad ulama dan hakim, yang menjadikan pendapat dari ijtihad mereka suatu keharusan untuk ditaati, padahal hal tersebut hanya merupakan hasil pemikiran manusia yang bisa berubah sesuai dengan tempat dan waktu (Asymawi, 1996:130). 
Dalam Islam, $t a$ 'zîr merupakan keputusan terpenting dalam menentukan hukuman (Asymawi, 1996:129).

Dalam penerapan undang-undang pidana di Mesir bisa dikatakan bahwa hukuman yang ada merupakan ta'zîr yang merupakan hak seorang hakim -yaitu kekuasaan khusus sesuai dengan undang-undang terbaru-tasyrî'iyyat atau qadla'iyyat (Asymawi, 1996:233).

Maka undang-undang tersebut tidak menyalahi syari'at bahkan ia sangat penting diterapkan demi kemaslahatan masyarakat (Asymawi, 1996:233). Dan dalam penerapan hukuman tersebut harus berpegang pada landasan pokok yaitu penerapannya dilakukan pada masyarakat yang adil dan bertakwa, sehingga tercapai tujuan penerapan hukuman $t a$ 'zîr tersebut, yaitu menyeru yang hak dan melarang yang bathil (Asymawi, 1996:130).

Nur Laiatul Musyafa'ah (2008) mengungkapkan bahwa hukum pidana Islam dapat diterapkan apabila hukum pidana Islam telah diimani oleh manusia. Manusia sangat membutuhkan hukum pidana Islam untuk menyelesaikan pelanggaran Hak Syar'i Manusia agar terbentuk negara yang baldayatun thoyibatun warbbun ghofur (aman, tentram, damai dan sejahtera).

Konsep Hukum Pidana Had Zina dalam penelitian ini adalah: Had zina muhshon dan ghoiru muhshon $\mathrm{Ta}^{\prime}$ zir yang terkait dengan pendekatan zina.

Berdasarkan uraian diatas maka dapat disimpulkan bahwa tanggapan pada hukum pidana had zina adalah gambaran ingatan dari pengalaman masa lampau, masa kini dan masa mendatang terhadap peraturan-peraturan yang mengatur tentang ancaman hukuman bagi pelanggar larangan Allah yang terkait dengan zina.

c. Sikap Taubatan Nashuha

Sikap adalah suatu bentuk dari perasaan, yaitu perasaan mendukung atau memihak (favourable) maupun perasaan tidak mendukung (Unfavourable) pada suatu objek (Sri Rahayu Utaminingsih, 2008). Sikap adalah istilah yang mencerminkan senang, tidak senang atau perasaan biasa-biasa saja (netral) dari sesorang terhadap sesuatu. Sesuatu itu bisa benda, situasi, kejadian, orang-orang atau kelompok. Kalau yang timbul terhadap sesuatu itu adalah perasaan senang, maka disebut sikap positif, sedangkan kalau perasaan 
tidak senang, sikap negatif. Kalau tidak timbul perasaan apa-apa, berarti sikapnya netral (Sarwono, 2009:201).

Sikap dinyatakan dalam tiga komponen ABC, yaitu Affect, Behaviour dan Cognition. Affect adalah perasaan yang timbul (senang, tak senang), Behaviour perilaku yang mengikuti perasaan itu (mendekat, menghindar), dan Cognition adalah penilaian terhadap sikap itu (bagus, tidak bagus) (Sarwono, 2009:201).

Menurut Mar'at (1984) komponen sikap adalah: Komponen kognisi yang berhubungan dengan belief (kepercayaan atau keyakinan), ide, konsep. Komponen afeksi yang berhubungan dengan kehidupan emosional seseorang.

Komponen kognisi yang merupakan kecenderungan bertingkah laku

Muhammad Shohib (2009) menyatakan taubat dapat diartikan sebagai kesadaran yang diikuti dengan penyesalan dan keinginan kuat untuk meninggalkan perbuatan dosa dan berupaya memperbaiki kesalahan di masa lalu. Taubatan Nashuha yaitu suatu perbuatan yang berpindah dari perbuatan buruk ke perbuatan baik yang terus menerus konsisten dan istiqomah.

Berdasarkan uraian diatas dapat disimpulkan pengertian sikap taubatan nashuha adalah suatu perasaan, keyakinan dan perbuatan individu yang berpindah dari perbuatan buruk ke perbuatan baik yang terus menerus dan istiqomah.

Pada hakekatnya taubat jika dilihat dari aspek kejiwaan adalah suatu kombinasi dari fungsi-fungsi kejiwaan yang mampu merevitalisasi kondisi psikologis manusia. Fungsi-fungsi kejiwaan tersebut antara lain: Kesadaran; Pengakuan dosa (al I'tiraf); Penyesalan (al Nadam); Komitmen; Perbuatan baik yang terus menerus

Hipotesa

Hipotesa penelitian ini adalah: Tanggapan masa lalu sama dengan Sikap kognitif;Tanggapan masa kini sama dengan Sikp Afektif; Tanggapan masa datang sama dengan Sikap Motorik; Tanggapan pada had zina sama dengan Sikap Taubatan nashuha

\section{Hasil Penelitian}

Penelitian tentang tanggapan pada hukum pidana Islam terhadap sikap taubatan nashuha dengan jenis penelitian kuantitatif dan desain Ex-post-facto. Populasi berjumlah 83 siswa Sekolah Menengah Kejurusan Cendekia Madiun. Teknik pengumpulan data dengan dokumen dan angket dimana tiap variabel ada tiga indikator, masing-masing variabel 20 item. Analisa datanya dengan test $\mathrm{t}$ 
yang menunjukan bahwa tidak ada beda antara Tanggapan masa lalu dengan Sikap kognitif; Tanggapan masa kini dengan Sikap afektif; Tanggapan masa datang dengan Sikap motorik dan Tanggapan pada had zina dengan Sikap taubatan nashuha.

\section{Pembahasan Hasil Penelitian}

Manusia hidup di dunia membutuhkan peraturan baik berupa perintah maupun larangan. Peraturan perintah untuk mempermudah manusia melakukan aktifitasnya dalam rangka mengabdi pada Allah dan peraturan yang berupa larangan agar hidup manusia tidak tersesat. Oleh karena itu manusia wajib mempelajari, memahami peraturan Allah agar mereka mempunyai tanggapan yang positip baik tanggapan masa lalu, masa kini dan masa datang untuk berbanding lurus dengan sikap baik sikap kognitif, afektif dan motorik untuk bertaubatan nashuha.

Berdasar hasil penelitian diatas menunjukan bahwa ketika siswa mendapat bimbingan sejak usia dini tentang zina maka tanggapan masa lalu mereka berbanding lurus dengan sikap kognitif mereka, tanggapan masa kini mereka berbanding lurus dengan sikap afektif mereka, tanggapan masa datang mereka berbanding lurus dengan sikap motorik mereka. Tanggapan mereka pada had zina berbanding lurus dengan sikap taubatan nashuha. Jadi tanggapan mereka akan menjadi filter sikap mereka untuk berprilaku. Tanggapan mereka positif maka sikap mereka juga positif.

\section{Simpulan}

Hasil penelitian ini dapat disimpulkan bahwa tanggapan pada Had Zina berbanding lurus dengan sikap taubatan nashuha.

\section{Saran}

Berdasarkan simpulan di atas, dapat diberikan saran sebagai berikut:

1. Bagi SiswaUsia SMK

Siswa SMK hendaklah selalu mempelajari peraturan Allah khususnya terkait dengan sanksi perbuatan dosa besar, agar memiliki tanggapan positif pada semua peraturan Allah ehingga mempercepat bersikap Taubatan Nashuha.

2. Bagi Sekolah

Semua unsur sekolah untuk membimbing, memberi contoh dan maudiajak dialog oleh para muridnya kapan, dimana saja dan mengenai apa saja. .

3. Bagi Peneliti Selanjutnya

Peneliti selanjutnya dapat memperhatikan faktor lain yang dapat mempengaruhi munculnya sikap taubatan nashuha. 


\section{DAFTAR PUSTAKA}

Agama.

2006, Al- Qur'an dan Terjemahannya, Jakarta:Departemen

-,Konsep Hukum Pidana Islam: Hukuman Diat Untuk Ibanah (Perusakan) Athrof Dan Sejenjsnya:http://ngobrolislami.wordpress.com/

F.J.Monks, A.M.P. Knoers, Siti Rahayu haditomo, 2004, Psikologi Perkembangan Pengantar Dalam Berbagai Bagiannya, Yogyakarta: Gajah Mada University Press

Ikhwan. 2010.Pidana Hudud dalam Tinjauan Filsafat Hukum Islam. Innovatio, Vol. IX, No. 2, Juli-Desember 2010

Irwanto dkk, 2002, Psikologi Umum Buku Panduan Mahasiswa, Jakarta: P.T. Prenhalindo

Khallaf, 'Abd al-Wahhab. 1978. 'Ilm Ushul al-Fiqh. Al-Qahirah: Dar al-'Ilm li alThiba'ah wa al-Nasyr wa al-Tawzi'

LN, Syamsu Yusuf, 2007, Teori Kepribadian, Bandung: Remaja Rosdakarya Musyafa'ah, NurLailatul, 2008, Penerapan Hukum Pidana Islam Menurut Muhammad Sa,id Al- 'Asmawi, Jember:Jurnal Interest, Vol. 7, No 2, STAIN Jember, Oktober 2008

Mar'at, 1984. Sikap Manusia : Perubahan Serta Pengukurannya. Jakarta : Ghalia Indonesia.

Rohman, Aulia, 2012,Filsafat Hukum Pidana Islam,http://auliarahman12.depsos.org/2012/03/21/filsafat-hukum-islam/

Sarlito, W. Sarito, 2009, Pengantar Psikologi Umum, Jakarta: Rajawali Pers

Shaleh, Abdul Rahman, 2009, Psikologi Suatu Pengantar dalam Perspektif Islam, Jakarta: Kencana.

Sri Utami Rahayuningsih. 2008. Psikologi Umum 2 - Bab 1. Sikap (Attitude). http//:www.google.com. Diunduh 2 Januari 2013.

Sri Rumini, Siti Sundari H.S, 2004, Perkembangan Anak \& Remaja, Jakarta: P.T Renika Cipta.

Sugiyono, 2013, Cara Mudah Menyusun Skripsi Tesis Dan Disertasi, Bandung: ALFABETA.

Sugiyono, 2013, Metode Penelitian Kuantitatif, Kualitatif, Dan Kombinasi (Mixed Methods). 